\title{
Efektivitas Rendaman Daun Jati (Tectona grandis Linn.f) Dalam Mewarnai Stadium Telur Parasit STH (Soil Transmitted Helminth)
}

\section{Effectiveness of Teak Leaf (Tectona grandis Linn.f) Soaking in Coloring The Stage of Eggs STH (Soil Transmitted Helminth) Parasites}

\author{
Puji Hastuti ${ }^{1}$, Dwi Haryatmi ${ }^{1}$ \\ ${ }^{1}$ Parasitologi, DIII Teknologi Laboratorium Medik, STIKES Nasional Surakarta, Sukoharjo \\ Riwayat Artikel: Diterima September 2021; Diterbitkan Oktober 2021
}

\begin{abstract}
Abstrak
Penyakit cacingan merupakan masalah kesehatan yang masih banyak ditemukan di dunia, hampir 2 miliar orang terinfeksi Soil Transmitted Helminth (STH). Cacing yang tergolong STH adalah Ascaris lumbricoides, Trichuris trichiura dan cacing tambang (Ancylostoma duodenale dan Necator americanus). Diagnosis penyakit cacingan ditegakkan dengan pemeriksaan mikroskopis tinja yang ditunjang dengan pewarnaan. Eosin dan lugol selama ini digunakan sebagai pewarna pada pemeriksaan mikroskopis tinja. Daun jati (Tectona grandis Linn.f) mengandung senyawa antosianin yang dapat digunakan sebagai pewarna alami. Tujuan penelitian ini untuk mengetahui kemampuan rendaman daun jati dalam mewarnai stadium telur parasit STH jika dibandingkan dengan pewarna eosin $2 \%$ dan lugol $2 \%$. Metode pemeriksaan tinja yang digunakan adalah metode sedimentasi. Rendaman daun jati diperoleh dengan cara merendam daun jati dengan Etanol $96 \%$ dan $\mathrm{HCl}$ pekat selama 24 jam. Hasil pewarnaan menggunakan rendaman daun jati memberikan nilai efektif $100 \%$ pada telur Ascaris sp. dan Trichuris sp., dan memberikan nilai efektif $66,7 \%$ pada telur Hookworm. Berdasarkan perhitungan uji Chi-square dan tabel Fisher Exact dapat disimpulkan bahwa rendaman daun jati memiliki kemampuan yang signifikan seperti eosin $2 \%$ dan lugol $2 \%$ dalam mewarnai stadium telur parasit STH.
\end{abstract}

Kata Kunci : rendaman daun jati, telur STH, pewarna alternatif

\begin{abstract}
Worm disease is a health problem that is widely found in the world, nearly 2 billion people are infected with the Soil Transmitted Helminth (STH). Worms belonging to STH are Ascaris lumbricoides, Trichuris trichiura and hookworms (Ancylostoma duodenale and Necator americanus). The diagnosis of intestinal worms is confirmed by microscopic examination of the feces supported by staining. Eosin and lugol have been used as dyes on microscopic examination of feces. Teak leaf (Tectona grandis Linn.f) contain anthocyanin compounds that can be used as natural dyes. The purpose of this study was to determine the ability of soaked teak leaf to color the egg stage of the STH parasite when compared with eosin $2 \%$ and lugol $2 \%$. The stool examination method used was sedimentation method. The teak leaf soak was obtained by soaking teak leaf with ethanol $96 \%$ and concentrated HCL for 24 hours. The results of staining using teak leaf gave an effective value of $100 \%$ on Ascaris sp. ang Trichuris sp. eggs, and gave an effective value of $66,7 \%$ on Hookworm eggs. Based on the Chi-square test calculations and the Fisher Exact tables, it can be determined that the teak leaf has such significant capabilities as eosin $2 \%$ and lugol $2 \%$ in coloring the eggs stage of the STH parasites.
\end{abstract}

Keywords: teak leaf soak, STH eggs, alternative dyes 


\section{Pendahuluan}

Penyakit cacingan merupakan masalah kesehatan yang masih banyak ditemukan di dunia. Hampir 2 miliar orang (sekitar seperempat populasi dunia) terinfeksi Soil Transmitted Helminth (WHO, 2017). Prevalensi cacingan di Indonesia pada umumnya masih sangat tinggi, terutama pada golongan penduduk yang kurang mampu, dengan sanitasi buruk. Prevalensi cacingan bervariasi antara 2,5-62\% (Kemenkes RI, 2017).

Pemeriksaan tinja merupakan gold standard untuk menegakan diagnosis infeksi yang disebabkan oleh cacing (Ramadhini dan Mutiara, 2015). Pemeriksaan tinja terdapat beberapa cara seperti pemeriksaan langsung (direct slide), metode flotasi/pengapungan, metode selotip, teknik sediaan tebal dan metode sedimentasi (Regina, 2018). Metode sedimentasi memiliki kelebihan yaitu mampu menemukan jumlah telur lebih banyak, dapat mengendapkan telur tanpa merusak, dan jarang mendapatkan hasil negatif palsu dibandingkan metode flotasi (Aryawan, 2019).

Dalam pemeriksaan tinja untuk identifikasi telur cacing perlu ditunjang dengan pewarnaan. Pewarnaan telur cacing bertujuan untuk memudahkan dalam mempelajari bentuk telur cacing, mempertegas, dan melihat bentuk serta kontras pada preparat telur cacing dengan menggunakan mikroskop (Oktari dan Mu'tamir, 2017). Kelemahan penggunaan eosin pada sediaan langsung yaitu membutuhkan banyak reagen dan dibandingkan dengan bahan alam, eosin lebih mahal (Sari dan Artanti, 2020).

Salah satu tumbuhan yang dapat berpotensi sebagai pewarna alami adalah daun jati (Tectona grandis Linn.f.) (Mutmainnah, 2018). Daun jati muda memiliki kandungan pigmen yang berupa senyawa flavonoid yaitu antosianin. Antosianin merupakan pigmen yang dapat memberikan warna biru, ungu, violet, magenta, merah, dan oranye pada bagian tanaman seperti buah, sayuran, bunga, daun, akar, umbi, legum, dan sereal (Fathinatullabibah, 2014). Senyawa antosianin dalam daun jati memberikan pigmen warna merah (Pratama, 2013). Dalam penelitian Virgianti (2017) ekstrak kombinasi angkak dan daun jati dapat sebagai pewarna penutup pada pewarnaan gram. Berdasarkan latar belakang tersebut, maka perlu dilakukan penelitian mengenai Efektivitas Rendaman Daun Jati
(Tectona Grandis Linn.f) dalam Mewarnai Stadium Telur Parasit STH (Soil Trasmitted Helminth).

\section{Metode Penelitian}

Jenis penelitian yang digunakan adalah analitik eksperimental. Daun jati (Tectona grandis Linn.f) diperoleh di desa Pondok, Kecamatan Grogol, Sukoharjo. Tempat penelitian dan pembuatan rendaman dilakukan di Laboratorium Parasitologi STIKES Nasional Surakarta. Pemeriksaan tinja menggunakan metode sedimentasi. Stadium telur parasit STH (Soil Trasmitted Helmith) dalam penelitian ini adalah menggunakan model stadium telur parasit STH (Soil Trasmitted Helmith) yakni Ascaris sp., Hookworm, Trichuris sp. yang ditemukan dalam tinja hewan babi, kucing, dan tikus. Teknik sampling yang digunakan adalah quota sampling.

\section{Alat}

Alat yang digunakan antara lain : Alat Pelindung Diri (Handscon, masker, jas lab), tempat sampel, tabung reaksi/tabung centrifuge, batang pengaduk, rak tabung reaksi, pinset, pipet tetes, object glass, deck glass, kassa, kertas saring, becker glass, gunting, timbangan elektrik, mikroskop, centrifuge, botol coklat, label, lidi.

\section{Bahan}

Bahan yang digunakan adalah Eosin 2\%, Lugol 2\%, air/aquades, Etanol 96\%, $\mathrm{HCl}$ pekat, tinja babi, tinja kucing, tinja tikus, daun jati (Tectona grandis Linn.f).

\section{Tahapan Penelitian}

1. Pembuatan rendaman daun jati (Tectona grandis Linn.f)

Daun jati (Tectona grandis Linn.f) dengan kriteria daun yang berada di pucuk sampai nodus ketiga dari batang baik yang masih menggulung maupun yang sudah membuka dan berwarna hijau kemerahan (Nurwanti dkk, 2013). Kemudian dipotong kecil-kecil lalu ditimbang sebanyak $100 \mathrm{~g}$ dengan timbangan elektrik. Selanjutnya dimasukkan ke dalam beckerglas, ditambahkan pelarut Etanol 96\% sebanyak $99 \mathrm{ml}$ dan $\mathrm{HCl}$ pekat sebanyak $1 \mathrm{ml}$. Direndam selama 24 jam kemudian disaring dengan kertas saring. Simpan larutan dalam botol coklat (Pratama, 2013). 
2. Pemeriksaan tinja metode sedimentasi

Tinja dimasukkan ke dalam gelas becker lalu ditambahkan air/aquades dengan perbandingan 1:10, kemudian diaduk sampai rata selanjutnya disaring, hasil saringan dimasukkan ke dalam tabung sentrifus. Kemudian disentrifus selama 2-5 menit dengan kecepatan $1500 \mathrm{rpm}$. Supernatan dibuang, sedangkan endapannya ditambahkan air lagi seperti tahap sebelumnya kemudian disentrifus lagi selama 2-5 menit dengan kecepatan 1500 rpm. Proses ini diulang sampai mendapatkan supernatan yang jernih. Setelah jernih, supernatan dibuang dan disisakan endapan untuk pemeriksaan mikroskopis (Paramitha dkk, 2017). Telur Ascaris sp., Hookworm, Trichuris sp. diperiksa dengan mikroskop sebanyak 9 preparat sediaan untuk setiap pewarnaan.

3. Pewarnaan telur cacing

Satu tetes eosin $2 \%$ diteteskan di atas objek glass, tambahkan secukupnya sedimen sampel tinja kemudian emulsikan dan tutup dengan deck glass. Hati-hati agar tidak terjadi gelembung udara. Setelah itu diperiksa di bawah mikroskop dengan objektif 10x dan 40x (Idris dan Fusvita, 2017).

Satu tetes lugol 2\% diteteskan di atas objek glass, tambahkan secukupnya sedimen sampel tinja kemudian homogenkan, tutup dengan deck glass secara hati-hati. Kemudian periksa sediaan di bawah mikroskop dengan lensa objektif 10x dan 40x (Sihombing dan Mulyowati, 2018).

Satu tetes larutan rendaman daun jati (Tectona grandis Linn.f) diteteskan di atas objek glass, tambahkan secukupnya sedimen sampel tinja lalu homogenkan, tutup dengan deck glass secara hati-hati kemudian diperiksa di bawah mikroskop dengan lensa objektif 10x dan 40x.

\section{Analisa Data}

Pengamatan hasil pemeriksaan morfologi telur STH (Soil Trasmitted Helminth) dilakukan oleh 3 observer, pemeriksaan pada preparat dengan pewarna eosin $2 \%$, lugol $2 \%$, dan rendaman daun jati (Tectona grandis Linn.f) dilakukan sebanyak 9x pengulangan. Dalam penelitian ini digunakan

chi square dan jika tidak memenuhi syarat uji tersebut, maka uji yang dipakai adalah fishers exact test menggunakan perangkat lunak komputer SPSS.

\section{Hasil dan Pembahasan}

Penelitian terhadap efektivitas rendaman daun jati (Tectona grandis Linn.f) dalam mewarnai stadium telur parasit STH (Soil Transmitted Helminth) didapatkan hasil presentase hasil pewarnaan eosin $2 \%$ diperoleh hasil efektif 100\% terhadap telur Ascaris sp., efektif $100 \%$ terhadap telur Hookworm, efektif $88,9 \%$ dan tidak efektif $11,1 \%$ terhadap telur Trichuris sp. Hasil pewarnaan lugol 2\% diperoleh hasil efektif 100\% terhadap telur Ascaris sp., Hookworm, dan Trichuris sp. Hasil pewarnaan rendaman daun jati (Tectona grandis Linn.f) diperoleh hasil efektif $100 \%$ terhadap telur Ascaris sp., efektif 66,7\% dan tidak efektif $33,3 \%$ terhadap telur Hookworm, efektif 100\% terhadap telur Trichuris sp.

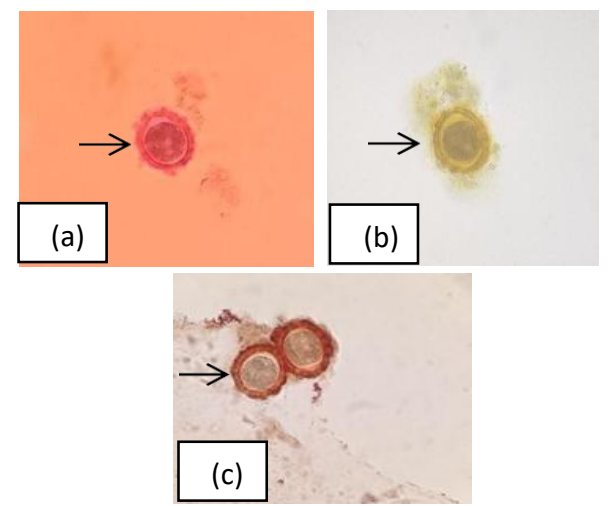

Gambar 1. Telur Ascaris sp. dengan perbesaran objektif 40x menggunakan pewarna : eosin $2 \%$ (a), lugol $2 \%$ (b), rendaman daun jati $100 \%$ (c)

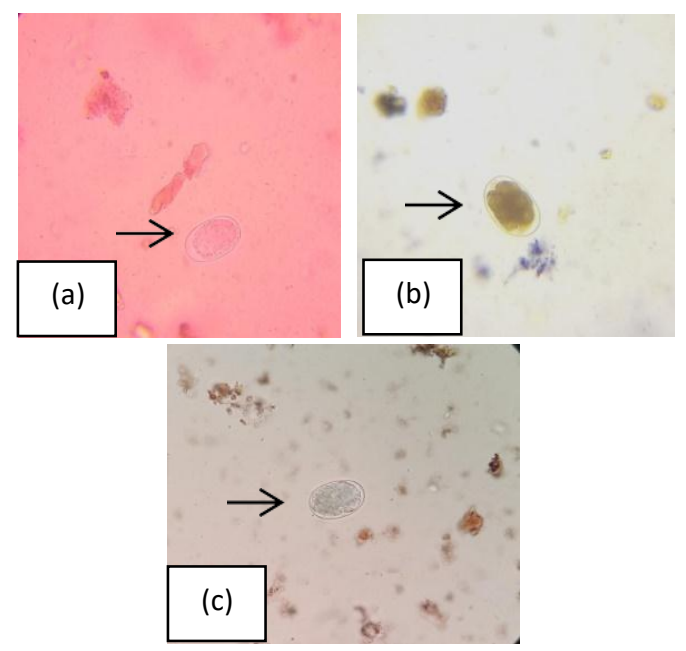

Gambar 2. Telur Hookworm dengan perbesaran objektif 40x menggunakan pewarna : eosin $2 \%$ (a), lugol $2 \%$ (b), rendaman daun jati $100 \%$ (c) 


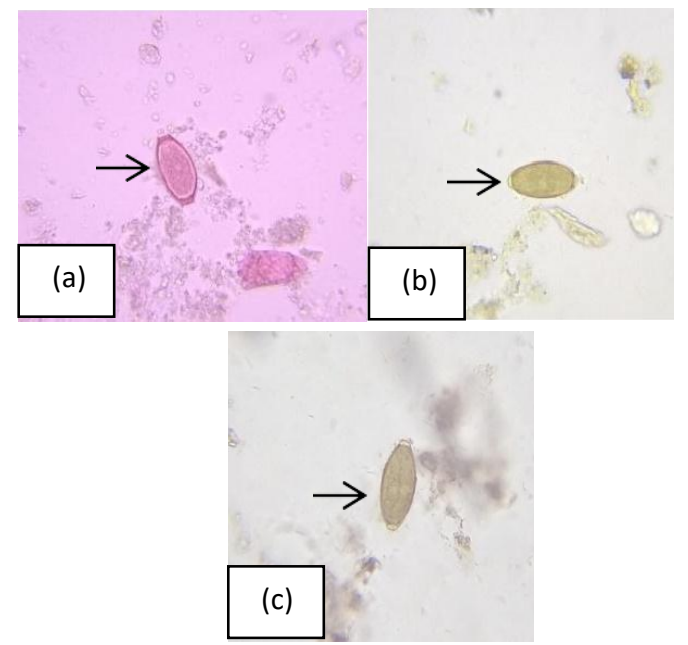

Gambar 3. Telur Trichuris sp. dengan perbesaran objektif 40x menggunakan pewarna : eosin $2 \%$ (a), lugol $2 \%$ (b), rendaman daun jati $100 \%$ (c)

Penilaian efektivitas pewarnaan pada telur Ascaris sp., Hookworm, Trichuris sp., dilakukan oleh 3 observer. Hasil akhir penilaian diambil dengan cara voting dengan kriteria penilaian yaitu skor 1: hasil tidak efektif apabila lapisan-lapisan dinding telur dan morula tidak terwarnai. Skor 2 : hasil efektif apabila lapisanlapisan dinding telur dan morula terwarnai. Hasil pengamatan telur Ascaris sp., Hookworm, Trichuris sp. disajikan dalam tabel berikut ini :

Tabel 1. Hasil pengamatan telur Ascaris sp.

\begin{tabular}{cccc}
\hline \multirow{2}{*}{$\begin{array}{c}\text { Pengula } \\
\text { ngan }\end{array}$} & \multicolumn{3}{c}{ Pewarna } \\
\cline { 2 - 4 } & $\begin{array}{c}\text { Eosin } \\
2 \%\end{array}$ & Lugol 2\% & $\begin{array}{c}\text { Rendaman } \\
\text { daun jati }\end{array}$ \\
\hline 1 & 2 & 2 & 2 \\
2 & 2 & 2 & 2 \\
3 & 2 & 2 & 2 \\
4 & 2 & 2 & 2 \\
5 & 2 & 2 & 2 \\
6 & 2 & 2 & 2 \\
7 & 2 & 2 & 2 \\
8 & 2 & 2 & 2 \\
9 & 2 & 2 & 2 \\
\hline
\end{tabular}

Tabel 2. Hasil pengamatan telur Hookworm

\begin{tabular}{cccc}
\hline Pengulangan & \multicolumn{3}{c}{ Pewarna } \\
\cline { 2 - 4 } & $\begin{array}{c}\text { Eosin } \\
2 \%\end{array}$ & $\begin{array}{c}\text { Lugol } \\
2 \%\end{array}$ & $\begin{array}{c}\text { Rendaman } \\
\text { daun jati }\end{array}$ \\
\hline 1 & 2 & 2 & 2 \\
2 & 2 & 2 & 1 \\
3 & 2 & 2 & 2 \\
4 & 2 & 2 & 2 \\
5 & 2 & 2 & 2 \\
6 & 2 & 2 & 2 \\
7 & 2 & 2 & 2 \\
8 & 2 & 2 & 1 \\
9 & 2 & 2 & 1 \\
\hline
\end{tabular}

Tabel 3. Hasil pengamatan telur Trichuris sp.

\begin{tabular}{cccc}
\hline Pengulangan & \multicolumn{3}{c}{ Pewarna } \\
\cline { 2 - 4 } & $\begin{array}{c}\text { Eosin } \\
2 \%\end{array}$ & Lugol 2\% & $\begin{array}{c}\text { Rendaman } \\
\text { daun jati }\end{array}$ \\
\hline 1 & 2 & 2 & 2 \\
2 & 2 & 2 & 2 \\
3 & 2 & 2 & 2 \\
4 & 1 & 2 & 2 \\
5 & 2 & 2 & 2 \\
6 & 2 & 2 & 2 \\
7 & 2 & 2 & 2 \\
8 & 2 & 2 & 2 \\
9 & 2 & 2 & 2 \\
\hline
\end{tabular}

Penilaian :

1. Tidak efektif

2. Efektif

Pewarnaan menggunakan rendaman daun jati (Tectona grandis Linn.f) terhadap telur Ascaris sp. memberikan hasil dengan latar belakang terang sehingga mudah dibedakan dengan telur. Lapisan albumin, glikogen, dan lipoidal berwarna coklat kemerahan sampai coklat gelap dengan morulla berwarna kuning kecoklatan. Pada pewarnaan telur Hookworm memberikan hasil telur pada lapisan vitelline berwarna coklat kemerahan dan morulla berwarna abu-abu, dengan latar belakang terang. Pada pewarnaan telur Trichuris sp., memberikan hasil telur pada lapisan vitelline dan kitin berwana coklat gelap, lipid berwarna coklat dan morulla berwarna coklat muda dengan latar belakang terang.

Hasil penelitian selanjutnya dianalisa menggunakan SPSS dengan uji Chi-square dan uji Fisher Exact sebagai uji alternatif. Uji Fisher Exact digunakan sebagai uji alternatif karena 
pada uji Chi-square ada syarat yang tidak terpenuhi yaitu ada nilai expected $<5(50,0 \%)$. Uji Chi-square dan uji Fisher Exact digunakan untuk mengetahui kemampuan eosin $2 \%$, lugol $2 \%$, dan rendaman daun jati (Tectona grandis Linn.f) dalam mewarnai stadium telur parasit STH (Soil Transmitted Helminth). Pada pengamatan telur Ascaris sp. dengan pewarna eosin $2 \%$, lugol $2 \%$, dan rendaman daun jati (Tectona grandis Linn.f) diperoleh hasil efektif 100\%. Dari hasil perhitungan uji Chi-square didapatkan hasil $\mathrm{X}^{2}$ hitung $(0)<\mathrm{X}^{2}$ tabel nilai Chi kuadrat $(5,591)$. Maka Ho diterima, jadi dapat disimpulkan bahwa tidak ada perbedaan yang signifikan antara eosin $2 \%$, lugol $2 \%$, dan rendaman daun jati (Tectona grandis Linn.f) dalam mewarnai telur Ascaris sp.

Pada analisa telur Hookworm dengan pewarna eosin $2 \%$ dan lugol $2 \%$, dari hasil perhitungan uji Chi-square didapatkan hasil $\mathrm{X}^{2}$ hitung $(0)<\mathrm{X}^{2}$ tabel $(3,481)$. Dari uji Fisher Exact pada tabel eosin dan rendaman daun jati, dan pada tabel lugol dan rendaman daun jati diperoleh nilai p 0,103. Maka Ho diterima, jadi dapat disimpulkan bahwa tidak ada perbedaan yang signifikan antara eosin $2 \%$, lugol $2 \%$, dan rendaman daun jati (Tectona grandis Linn.f) dalam mewarnai telur Hookworm.

Pada analisa telur Trichuris sp. dengan pewarna lugol dan rendaman daun jati, dari hasil perhitungan uji Chi-square didapatkan hasil $\mathrm{X}^{2}$ hitung $(0)<\mathrm{X}^{2}$ tabel $(3,481)$. Dari uji Fisher Exact pada tabel eosin dan lugol, dan pada tabel eosin dan rendaman daun jadi diperoleh nilai p 0,500 . Nilai $p>0,05$ maka Ho diterima, sehingga dapat disimpulkan bahwa tidak ada perbedaan yang signifikan antara eosin $2 \%$, lugol $2 \%$, dan rendaman daun jati (Tectona grandis Linn.f) dalam mewarnai stadium telur Trichuris sp. Rendaman daun jati (Tectona grandis Linn.f) memiliki kemampuan yang signifikan seperti eosin $2 \%$ dan lugol $2 \%$ dalam mewarnai stadium telur parasit STH (Soil Transmitted Helminth).

Telur Ascaris sp., Hookworm, Trichuris sp. dalam penelitian ini diperoleh dari tinja babi, kucing, dan tikus yang diperiksa dengan menggunakan metode sedimentasi. Metode sedimentasi dipilih karena memiliki kelebihan yaitu mampu menemukan jumlah telur lebih banyak, dapat mengendapkan telur tanpa merusak, dan jarang mendapatkan hasil negatif palsu bila dibandingkan dengan metode flotasi (Aryawan, 2019). Sampel tinja yang telah selesai dilakukan sedimentasi selanjutnya dilakukan pemeriksaan mikroskopis dengan pewarna eosin $2 \%$, lugol $2 \%$, dan rendaman daun jati (Tectona grandis Linn.f).

Eosin merupakan pewarna sintetis yang termasuk golongan Xanthene. Eosin yang bersifat asam akat mengikat molekul protein yang bermuatan positif di sitoplasma dan jaringan ikat. Eosin akan mewarnai sitoplasma dan jaringan ikat menjadi bernuansa merah dan orange. Eosin Y (yellowish) paling banyak digunakan karena termasuk dalam zat warna asam sehingga dapat berikatan dengan protein yang bersifat basa dan dapat berpenetrasi pada struktur padat dan bersifat metakromatik yang terdapat dalam 2 bentuk yaitu monomer (merah) dan dimer (orange merah) (Saputra, 2019). Protein merupakan molekul penyusun lapisan telur yang bersifat basa dan bermuatan positif sehingga dapat dengan mudah berikatan dengan molekul eosin yang bersifat asam dan bermuatan negatif.

Larutan lugol iodin sering digunakan untuk pemeriksaan mikroskopis parasit salah satunya dalam mencari trofozoit dan kista. Larutan lugol iodin menyebabkan trofozoit menjadi non motil dan nukleus terwarnai dengan jelas, tetapi sukar untuk membedakan antara bentuk trofozoit dan kista. Dalam identifikasi telur cacing pemeriksaan menggunakan lugol, ditujukan untuk membedakan telur cacing dengan kotoran disekitarnya sehingga lebih jelas terlihat. Lugol memberikan latar belakang bening, kekuningan pada telur cacingnya (Oktapyani, 2016).

Daun jati (Tectona grandis Linn.f.) merupakan salah satu tumbuhan yang dapat berpotensi sebagai pewarna alami. Pada simplisia ekstrak etanol daun jati mengandung senyawa flavonoid, alkaloid, tanin, dan saponin. Daun jati muda memiliki kandungan pigmen yang berupa senyawa flavonoid yaitu antosianin. Antosianin merupakan pigmen yang dapat memberikan warna biru, ungu, violet, magenta, merah, dan oranye pada bagian tanaman seperti buah, sayuran, bunga, daun, akar, umbi, legum, dan sereal (Fathinatullabibah, 2014). Daun jati (Tectona grandis Linn.f) dipilih daun yang masih muda dari pucuk sampai nodus ke 3 dikarenakan dalam daun jati yang masih muda tersebut memiliki kandungan antosianin yang cukup tinggi (Nurwanti, 2013). Daun jati (Tectona grandis Linn.f) yang direndam dengan etanol 
$96 \%$ dan $\mathrm{HCl}$ pekat selama 24 jam menghasilkan larutan yang berwarna merah. Pewarnaan telur STH menggunakan rendaman daun jati (Tectona grandis Linn.f) memberikan hasil dengan latar belakang terang sehingga mudah dibedakan dengan telur. Pemanfaatan kandungan senyawa antosianin dalam daun jati (Tectona grandis Linn.f) sebagai pewarna alami yang aman bagi kesehatan dan lingkungan.

\section{Simpulan}

Berdasarkan hasil penelitian yang telah dilakukan, maka dapat disimpulkan bahwa rendaman daun jati (Tectona grandis Linn.f) mampu mewarnai stadium telur parasit STH (Soil Transmitted Helminth) dan memiliki kemampuan yang sama dengan pewarna eosin $2 \%$ dan lugol $2 \%$.

\section{Ucapan Terima Kasih}

Terima kasih kepada bapak/ibu instruktur laboratorium, laboran, dan staf Laboratorium Parasitologi STIKES Nasional Surakarta yang telah banyak membantu sehingga penelitian ini berjalan dengan lancar

\section{Daftar Pustaka}

Agni, F. (2018). Identifikasi Telur Cacing STH (Soil transmitted Helminth) Pada Daun Kemangi (studi Jln. Kemuning, Candimulyo, Kabupaten Jombang). Karya Tulis Ilmiah. STIKES Insan Cendekia Medika Jombang.

Artanti, D., Sari, Y. E. S., \& Ariana, D. (2020). Perbedaan Kualitas Preparat Telur Cacing Gelang (Ascaris lumbricoides, Linn) Menggunakan Rendaman Batang Pohon Jati dan Kuncup Daun Jati. Prosiding Senakes 1.0, 1(1).

Aryawan, A. F. G. (2019). Identifikasi Keberadaan Telur Cacing Usus Pada Lalapan Sayuran Kubis (Brassica oleracea) di Warung Makan Pecel Lele Sepanjang Jalan Kaliurang KM 4, 5-24 Kota Yogyakarta. Karya Tulis Ilmiah. Universitas Islam Indonesia Yogyakarta.

Fathinatullabibah, F., Khasanah, L. U., \& Kawiji, K. (2014). Stabilitas antosianin ekstrak daun jati (Tectona grandis) terhadap perlakuan $\mathrm{pH}$ dan suhu. Jurnal Aplikasi Teknologi Pangan, 3(2), 60-63.

Idris, S. A., \& Fusvita, A. (2017). Identifikasi Telur Nematoda Usus (Soil Transmitted Helmints) Pada Anak di Tempat
Pembuangan Akhir (TPA) Puuwatu.

Biowallacea, 4(1), 566-571.

Kemenkes Republik Indonesia. (2017). PMK Penanggulangan Cacingan. Jakarta : Kementerian Kesehatan Republik Indonesia.

Mutmainnah, D. (2018). Ekstraksi dan Uji Stabilitas Zat Warna Alami dari Daun Jati (Tectona grandis Linn.f.) sebagai Pengganti Pewarna Sintetik pada Produk Minuman. Skripsi. Universitas Islam Negeri Alauddin Makassar.

Nurwanti, M. (2013). Pemanfaatan filtrat daun muda jati sebagai bahan pewarna alternatif dalam pembuatan preparat jaringan tumbuhan. BioEdu, 2(1), 73-76.

Oktari, A., \& Mu'tamir, A. (2017). Optimasi Air Perasan Buah Merah (Pandanus sp.) Pada Pemeriksaan Telur Cacing. Jurnal Teknologi Laboratorium, 6(1), 8-17.

Paramitha, R. P., Ernawati, R., \& Koesdarto, S. (2017). Prevalensi Helminthiasis Saluran Pencernaan Melalui Pemeriksaan Feses pada Sapi di Lokasi Pembuangan Akhir (LPA) Kecamatan Benowo Surabaya. Journal of Parasite Science, 1(1), 23-32.

Pratama, Y. (2013). Pemanfaatan Ekstrak Daun Jati (Tectona grandis Linn. F.) sebagai Indikator Titrasi Asam- Basa. Tesis. Universitas Negeri Semarang.

Rahmadhini, N. S., \& Mutiara, H. (2015). Pemeriksaan Kuku sebagai Pemeriksaan Alternatif dalam Mendiagnosis Kecacingan. Jurnal Majority, 4(9), 113117.

Regina, M. P., Halleyantoro, R., \& Bakri, S. (2018). Perbandingan Pemeriksaan Tinja Antara Metode Sedimentasi Biasa Dan Metode Sedimentasi Formol-Ether Dalam Mendeteksi Soil-Transmitted Helminth. Diponegoro Medical Journal, 7(2), 527-537.

Sari, Y. E. S., \& Artanti, D. (2020). Optimasi Rendaman Batang Pohon Jati (Tectona grandis) Dalam Pemeriksaan Soil Transmitted helmint. Jurnal Teknologi Laboratorium Medik, 1(1), 1-6.

Sihombing, F. U., \& Mulyowati, T. (2018). Identifikasi Telur Cacing Hookworm, Toxocara vitulorum pada Feses Peternak Sapi dan Feses Sapi di Peternakan Sapi Dusun Karangnongko, Boyolali. Biomedika, 11(2), 76-78. 
Virgianti, D. P. (2017). Penggunaan Ekstrak Kombinasi Angkak dan Daun Jati Sebagai Pewarna Penutup Pada Pewarnaan Gram. Jurnal Kesehatan Bakti Tunas Husada: Jurnal Ilmu-ilmu Keperawatan, Analis Kesehatan dan Farmasi, 17(1), 66-72.
World Health Organization. (2017). Guideline: preventive chemotherapy to control soil- transmitted helminth infections in at- risk population groups. World Health Organization. 